\section{References}

Cowie, J. W. \& Adams, P. J. 1957: The geology of the Cambro-Ordovician rocks of central East Greenland. Meddr Grønland 153(1), 193 pp.

Cowie, J. W. \& Spencer, A. M. 1970: Trace fossils from the late Precambrian/Lower Cambrian of East Greenland. In Crimes, T. P. \& Harper, J. C. (edit.) Trace fossils. Geol. Jour. Spec. Issue 3, 91-100.

Crimes. T. P. 1987: Trace fossils and correlation of late Precambrian and early Cambrian strata. Geol. Mag. 124, 97-119.

Frykman, P. 1978: Investigation of Lower Palaeozoic rocks in northern East Greenland. Rapp. Grønlands geol. Unders. 90, 107-109.

Frykman, P. 1979: Cambro-Ordovician rocks of C. H. Ostenfeld Nunatak, northern East Greenland. Rapp. Grønlands geol. Unders. 91, 125-132.

Hambrey, M. J. \& Spencer, A. M. 1987: Late Precambrian glaciation of central East Greenland. Meddr Grønland, Geosci. 19, 50 pp.

Henriksen, N. 1985: The Caledonides of central East Greenland, $70^{\circ}-76^{\circ}$ N. In Gee, D. G. \& Sturt, B. A. (edit.) The Caledonide Orogen - Scandinavia and related areas, 10951113. Chichester: John Wiley \& Sons.
Henriksen, N. \& Higgins, A. K. 1976: East Greenland Caledonian fold belt. In Escher, A. \& Watt, W. S. (edit.) Geology of Greenland, 182-247. Copenhagen: Geol. Surv. Greenland.

Herrington, P. M. \& Fairchild, I. J. in press: Carbonate shelf and slope facies evolution prior to Vendian glaciation, central East Greenland. In Gayer, R. A. (edit.) The Caledonide geology of Scandinavia. London: Graham \& Trotman.

Koch, L. \& Haller, J. 1971: Geological map of East Greenland $72^{\circ}-76^{\circ}$ N. Meddr Grønland 183, 26 pp.

Moncrieff, A. C. M. in press: The Tillite Group and related rocks of East Greenland: implications for late Proterozoic palaeogeography. In Gayer, R. A. (edit.) The Caledonide geology of Scandinavia. London: Graham \& Trotman.

Poulsen, C. 1932: The Lower Cambrian faunas of East Greenland. Meddr Grønland 87(6), $66 \mathrm{pp.}$

Poulsen, C. 1937: On the Lower Ordovician faunas of East Greenland. Meddr Grønland 119(3), 72 pp.

Smith, M. P. 1982: Conodonts from the Ordovician of East Greenland. Rapp. Grønlands geol. Unders. 108, 14 only.

Smith, M. P. 1985: Ibexian - Whiterockian (Ordovician) conodont palaeontology of East and eastern North Greenland. Unpublished Ph.D thesis, Univ. Nottingham, 364 pp.

M. J. H.,

Scott Polar Research Institute,

University of Cambridge,

Lensfield Road,

Cambridge CB2 1ER,

U.K.

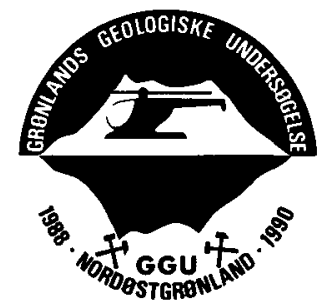

\title{
Sedimentological and structural investigations of the Devonian basin, East Greenland
}

\author{
P.-H. Larsen, H. Olsen, F. O. Rasmussen \\ and U. G. Wilken
}

Sedimentological and structural studies of the Middle to Upper Devonian deposits in East Greenland were initiated in 1986 (Marcussen et al., 1987) and continued in 1987 (Marcussen et al., 1988) and in 1988. Field work was carried out from late June to late August, but during a three week period from late July to early August it was hampered by bad weather in the region. The 1988 activities were concentrated around Moskusoksefjord, on Gauss Halvø west of Gastisdal and in Moskusokselandet. Shorter periods were spent in Ole Rømer Land and in northern Hudson Land, with short visits to Ymer $\emptyset$ and Geographical Society $\emptyset$ (fig. 1).
Prior to the field work a 1:100 000 preliminary photogeological map was produced in GGU based partly on previous observations and partly on new stereographic studies of aerial photographs $(1: 150000)$ of the area north of Kejser Franz Joseph Fjord. The field work benefited greatly from this map and from a series of oblique photographs along Kejser Franz Joseph Fjord, Nordfjord and Moskusoksefjord, taken in 1987.

Two teams operated in the field. One team $(\mathrm{H}$. Olsen \& U. G. Wilken) studied the sedimentology of the Devonian succession and the other (P.-H. Larsen \& F. O. Rasmussen) the structural evolution of the basin. 


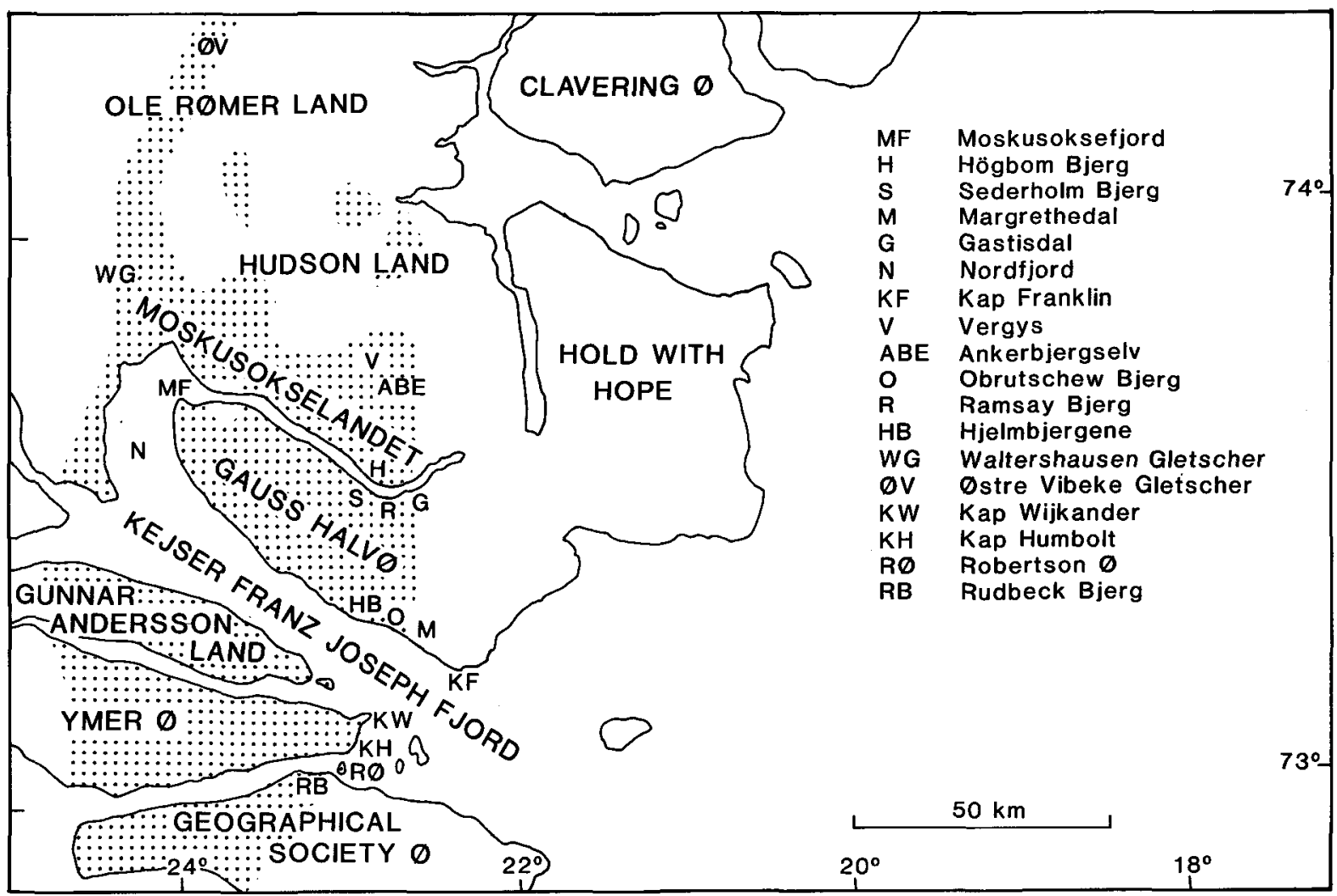

Fig. 1. The study area with localities mentioned in the text. The outcrop of the Devonian rocks is shown by dots.

Material for source rock analysis and samples for determining reservoir rock properties were collected by both teams.

\section{Sedimentology}

Four main lithostratigraphic units occur in the Devonian outcrop areas north of Scoresby Land (fig. 2). These are from the lowest upwards: Vilddal Supergroup, Kap Kolthoff Supergroup, Kap Graah Group and Mount Celsius Supergroup (Friend et al., 1983).

The Vilddal Supergroup is the oldest unit outcropping in the area. It represents the initial depositional phase of the Devonian basin. The Vilddal Supergroup is exposed in Moskusokselandet and on Gauss Halvø, and the majority of the Devonian strata in the Kap Franklin area (not visited in 1988) also belong to this supergroup. It starts with red conglomerates up to several hundred metres thick. These sediments are overlain by green sandstones which also attain several hundred metres in thickness and pass up into interbedded green and red sandstones and siltstones and locally black shales and carbonates.
The sequence reflects infilling of the initial topography by coarse sediments deposited by systems of eastwardly flowing gravelly rivers. As denudation of the landscape proceeded, the bedload changed from gravels to sands, and systems of eastwardly flowing sandy braided rivers deposited the thick pile of sand represented by the green sandstones. The valley gradients continued to decrease and the braided river pattern was replaced by a meandering river pattern represented by the green and red sandstone and siltstone succession. The meandering rivers flowed across huge flood basins. These flood basins were characterised by overbank sheet floods but locally lacustrine conditions were maintained for prolonged periods and black clays and carbonates were deposited.

The Kap Kolthoff Supergroup dominates in Hudson Land, Moskusokselandet and on Gauss Halvø. It is mainly composed of sandstones with subordinate conglomerates and volcanics. In Hudson Land sandstones of braided river origin dominate. Alluvial fan deposits, dominated by conglomerates, occur at the basin margin. In Moskusokselandet and on Gauss Halvø sandstones deposited by braided rivers dominate, but locally aeo- 


\begin{tabular}{|c|c|c|c|}
\hline \multirow{4}{*}{ U DEVONIAN } & Groenlandaspis Series & \multirow{2}{*}{ Mount Celsius Sp Grp } & \multirow{2}{*}{$1.2 \mathrm{~km}$} \\
\hline & Remigolepis Series & & \\
\hline & Phyllolepis Series & Kap Graah Grp & $1.7 \mathrm{~km}$ \\
\hline & \multirow{2}{*}{$\begin{array}{l}\text { Lower Sandstone } \\
\text { complex }\end{array}$} & Kap Kolthoff Sp Grp & $3.0 \mathrm{~km}$ \\
\hline M DEVONIAN & & Vilddal Sp Grp & $2.6 \mathrm{~km}$ \\
\hline
\end{tabular}

Fig. 2. Devonian stratigraphy. The biostratigraphical division is compiled from Säve-Söderberg (1934) and Jarvik (1961). The lithostratigraphical division is from Friend et al. (1983).

lian sandstones are important. Volcanoes, mainly acid, apparently formed local topographic barriers, splitting up the braidplains into segments. In this way sheltered parts of the basin floor were formed and wind-blown sands could be deposited and preserved.

Palaeocurrent directions in the Kap Kolthoff Supergroup are mainly southwards. A convergent pattern is, however, apparent: in the eastern part of the basin palaeocurrents are directed southwards whereas palaeocurrents in the western part of the basin are directed to the south-east. This indicates that the basin in Kap Kolthoff time was elongated north-south, characterised by a southward palaeoslope and dominated by infilling from east and west.

Palaeowinds are mainly from the south-east. This wind pattern probably indicates that the Devonian basin formed within an ancient trade wind belt characterised by easterly winds that were slightly deflected by the topography of the basin (elongation north-south).

The Kap Graah Group was studied in detail in Moskusokselandet, on Gauss Halvø and on Ymer $\varnothing$. It is dominated by sandstones with locally important siltstones and conglomerates.

In eastern Moskusokselandet the exposed lower Kap Graah Group is dominated by conglomerates deposited as gravels on alluvial or terminal fans. In western Moskusokselandet aeolian sandstones dominate the exposed lower part of the group, whereas sandstones of braided river origin are subordinate.

The lower part of the Kap Graah Group on Gauss Halv $\emptyset$ also exhibits a general trend from fluvial deposits in the east to aeolian deposits in the west. The fluvial deposits are dominated by sandstones deposited by braided rivers and ephemeral streams. The upper part of the group exposed in the eastern and central part of Gauss Halv $\emptyset$ is dominated by fluvial sandstones, deposited in a flood plain of braided-meandering rivers.

In eastern and central Gunnar Andersson Land on Ymer $\emptyset$ the lower part of Kap Graah Group is dom- inated by sandstones of braided river, ephemeral stream and aeolian origin (fig. 3). In the western part of the basin, meander belt deposits dominate with subordinate terminal mudflat deposits. The upper part of the group is almost missing. The exposed part consists, however, of braided-meandering river and ephemeral stream deposits in the eastern and central part and terminal mudflat deposits in the western part of the peninsula.

Palaeocurrents in the lower part of the Kap Graah Group are directed towards the west-south-west in the eastern and central part of the basin. In the western part of the basin, exposed in western Gunnar Andersson Land, palacocurrents are southwards. This indicates an asymmetric basin dominated by westwardly flowing rivers along the eastern basin margin and a longitudinal southwardly flowing meandering river close to the western basin margin.

Palaeocurrents in the upper Kap Graah Group are directed northwards indicating a reversal of the palaeoslope compared to the lower Kap Graah Group. Infilling of the basin continued, however, to be dominated by rivers with source areas east of the basin. Palaeowinds are from the south-east.

The Mount Celsius Supergroup forms the uppermost deposits in the Devonian basin. It is composed of a lower part, the Remigolepis Group, and an upper part, the Grönlandaspis Group. In the study area the supergroup is only exposed on Gauss Halvø and eastern Ymer $\varnothing$. The latter locality has previously been ascribed to the Carboniferous.

The Remigolepis Group is dominated by siltstones with subordinate sandstones of ephemeral stream origin, and associated overbank deposits. Near the base of the group there is an interval composed of ephemeral lake deposits and rare ephemeral stream deposits.

The Grönlandaspis Group is composed of alternating sandstones and siltstones in the lower part and almost exclusively of sandstones in the upper part. The lower part of the group was deposited by meandering rivers 


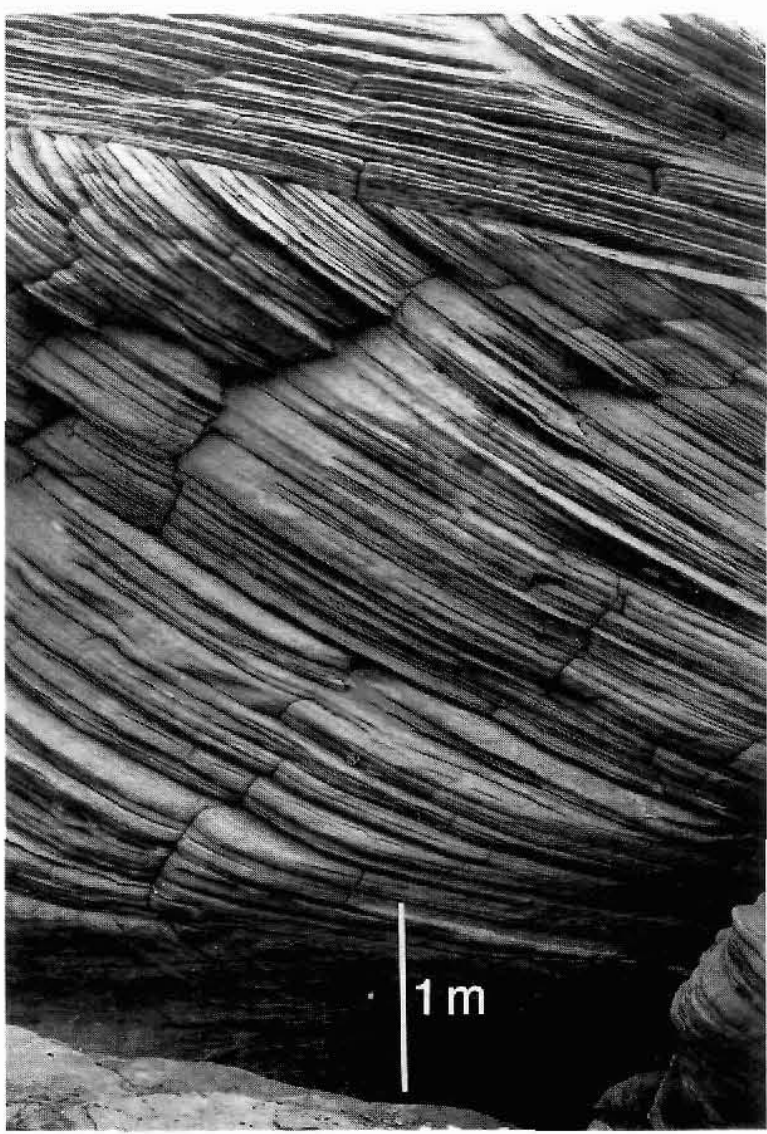

Fig. 3. Large-scale cross-bedded sandstone of aeolian dune origin. Wind blew from left. Locality: Gunnar Andersson Land (Kap Graah Group).

with associated overbank areas. The upper part was mainly deposited by braided rivers. Lacustrine shales and aeolian deposits occur locally.

Palaeocurrents in the fluvial deposits are directed towards the north, indicating that the northward palaeoslope initiated in upper Kap Graah time was maintained during deposition of the Mount Celsius Supergroup. Palaeowinds blew from the south-east, indicating a consistent palaeowind pattern throughout the depositional history of the basin.

Vertebrate fossils were collected in the Mount Celsius Supergroup on Gauss Halvø; these include finds of the earliest known tetrapods, Ichthyostega. Taphonomic and palaeoecologic investigations have been initiated in connection with these discoveries as a supplement to the palaeontological studies being carried out on Upper Devonian vertebrates by S. E. Bendix-Almgreen, Geologisk Museum, København and J. A. Clack, University Museum of Zoology, Cambridge (Bendix-Almgreen et al., 1988).

\section{Structure}

In accordance with Bütler (1959) and previous GGU observations (Marcussen, et al., 1988), the 1988 structural work in the Devonian basin shows that the early tectonic evolution and deformation during the Hudson Land phases (Bütler, 1959) were synchronous with the sedimentation. Lack of marker beds, especially in the lower sequence, and the 'non-layercake' type of sedimentation in the sandstone dominated continental environment, make mapping and structural work very complicated. Furthermore deformation outlasting the Devonian (the Carboniferous Ymer $\varnothing$ phase (Bütler, 1959) and probably even younger tectonic events) has left its imprint on the older structures and therefore has to be unravelled before the earlier Devonian structures can be sorted out.

Gauss Halv $\varnothing$ - Moskusokselandet. During the earliest deformation of the area, which affected sediments referred to the Vilddal Supergroup, a large synclinal structure was developed around the Vergys mountain and Ankerbjergselv. The north-west flank of this fold involves the upper parts of the Proterozoic Eleonore Bay Group which is tilted to an almost vertical position. Together with the uplifted basement of the Moskusoksefjord Inlier this flank became a positive topographic element influencing the subsequent sedimentation of the Kap Kolthoff Supergroup. The basin was subdivided into smaller segments which developed in separate ways. Volcanoes formed by acid magmatic activity during the deposition of the Kap Kolthoff Supergroup may also have added to the palaeotopography.

Just before the onset of deposition of the red-coloured Kap Graah Group sediments, the area around Högbom Bjerg - Sederholm Bjerg was uplifted and tilted towards the west. A boulder conglomerate was deposited along an angular unconformity on the older sediments. During the deposition of the Kap Graah Group renewed tectonic activity affected the Högbom Bjerg - Sederholm Bjerg area. The unconformity and the lower Kap Graah Group were folded and the Högbom Bjerg - Sederholm Bjerg upthrust developed. The area became eroded again before sediments of the upper Kap Graah Group and Mount Celsius Supergroup covered the area.

During the Ymer $\varnothing$ phase of deformation broadly undulating or open $\mathrm{N}-\mathrm{S}$ trending folds developed on Gauss Halvø. The structures cannot be followed across Moskusoksefjord to the north. In Moskusokselandet virtually no folding affecting the Upper Devonian sediments took place, except for a wide open syncline with hingeline in the Forbindelsesdal area. This geometric 
anisotropy across the rather straight Moskusoksefjord seems to indicate a different amount or mode of shortening on each side of the fjord. Moskusoksefjord is therefore most likely the site of a NW-SE striking fault that was active during the Ymer $\varnothing$ phase and possibly also important in earlier deformation phases.

West of the 'post-Devonian main fault' (Bütler, 1959) a narrow, westerly vergent syncline developed from Obrutschew Bjerg in the south to Ramsay Bjerg in the north. This fold, the Obrutschew Bjerg syncline, is bordered to the west by an almost linear fault which can be traced from Kejser Franz Joseph Fjord northwards to Ramsay Bjerg where it disappears. To the east the Obrutschew Bjerg syncline is cut by an angular unconformity and overlain by Upper Permian strata. This implies that the 'post-Devonian main fault' is not exposed on southern Gauss Halvø (contrast with Bütler, 1954, 1957; Koch Haller, 1971).

An occurrence of possible Upper Permian conglomerates was discovered on top of 'Mt Gunnbjørn' (of Säve-Söderbergh, 1934) in the Hjelmbjergene area lying uncomformably on slightly tilted Upper Devonian sediments. The conglomerates occur at approximately $1500 \mathrm{~m}$ altitude, whereas the same type of sediment 10 $\mathrm{km}$ to the east is found close to sea level. This indicates important Mesozoic or younger deformations in the Hjelmbjergene area.

In Prospektdal north of Moskusoksefjord new observations on the dark red and green coloured sediments on the east flank of Högbom Bjerg, which previously have been considered of Carboniferous age (Bütler, 1959; Koch \& Haller, 1971), indicate that these sediments are similar to Upper Devonian strata elsewhere on Gauss Halvø. The sediments can be referred to the Mount Celsius Supergroup, in which case they are the youngest known Devonian deposits preserved north of Moskusoksefjord.

Ole Rømer Land - northern Hudson Land. The Nordfjord graben (Bütler, 1959) was mapped NNE of Waltershausen Gletscher. The Devonian sediments are here concentrated in a narrow N-S striking graben $10-15 \mathrm{~km}$ wide bounded by nearly vertical faults. The base of the Devonian sequence, not hitherto known in the area, was found just east of $\emptyset$ stre Vibeke Gletscher where red-coloured conglomerates interbedded by sandstones overlie boulder conglomerates of the Eocambrian Tillite Formation.

Ymer $\emptyset$ - Geographical Society $\emptyset$. Sediments on Ymer $\emptyset$ and Geographical Society $\emptyset$ previously mapped as Carboniferous (Koch \& Haller, 1971) were remapped on a helicopter reconnaissance as they proved to be similar to Upper Devonian formations elsewhere in the area.

White sandstones previously mapped as Carboniferous are exposed from Kap Wijkander to Kap Humbolt and $15 \mathrm{~km}$ westward along the coastline of Dusén Fjord and Sofia Sund, on Robertson $\varnothing$ and on Geographical Society $\emptyset$ just east of Rudbeck Bjerg. These white sandstones are now referred to the Upper Devonian Sofia Sund Formation (Kap Kolthoff Supergroup). The sandstones are overlain by sediments similar to the Upper Devonian Mount Celsius Supergroup exposed elsewhere on Ymer $\emptyset$ and Geographical Society $\emptyset$ and are now mapped as such. The Devonian deposits are overlain by Carboniferous sandstones and shales, but these sediments only top the mountains and thus have a more restricted areal distribution than previously supposed. The Upper Devonian Kap Graah Group is missing in these areas.

\section{Reservoir properties and evidence of hydrocarbon generation}

The prediction of subsurface reservoir properties from surface material is very difficult. The problem is the timing of different diagenetic events in relation to hydrocarbon generation and migration. However, many representative samples have been collected this summer from the Devonian sediments in order to continue the reservoir studies of the Upper Palaeozoic and Mesozoic rocks of East Greenland (Stemmerik, 1988).

Black shales of potential source rock quality were collected at two localities in Moskusokselandet and at two localities on Gauss Halvø. These units attained thicknesses less than $10 \mathrm{~m}$ individually. Evidence of hydrocarbon generation was found as degraded bitumen at five localities, mainly in close association with black shales. The bitumen commonly occurs as fracture fillings in rocks, often associated with calcite growth. At one locality, however, the bitumen was disseminated in a sandstone. The black shale and bitumen occurrences have a wide stratigraphic spread as they were found in both the Middle Devonian Vilddal Supergroup and the Upper Devonian Kap Kolthoff and Mount Celsius Supergroups. The hydrocarbon source potential of the Devonian sequence is regarded as restricted.

Acknowledgements. H. Olsen's sedimentological studies in the Devonian basin are supported financially by the Carlsberg Foundation. N. Turner and B. Sikker Hansen helped prepare the manuscript and figures. 


\section{References}

Bendix-Almgreen, S. E., Clack, J. A. \& Olsen, H. 1988: Upper Devonian and Upper Permian vertebrates collected in 1987 around Kejser Franz Joseph Fjord, central East Greenland. Rapp. Grønlands geol. Unders. 140, 95-102.

Bütler, H. 1954: Die Stratigraphische Gliederung der Mitteldevonischen Serien im Gebiete von Kap Franklin an Kejser Franz Joseph Fjord in Zentral-Ostgrönland. Meddr Grønland 116(7), $126 \mathrm{pp}$.

Bütler, H. 1957: Beobachtungen an der Hauptbruchzone der Küste von Zentral-Ostgrönland. Meddr Grønland 160(1), 79 pp.

Bütler, H. 1959: Das Old Red-Gebiet am Moskusoksefjord. Meddr Grønland 160(5), 188 pp.

Friend, P. F., Alexander-Marrack, P. D., Allen, K. C., Nicholson, J. \& Yeats, A. K. 1983: Devonian sediments of East Greenland VI: review of results. Meddr Grønland 206(6), 96 pp.

Jarvik, E. 1961: Devonian vertebrates. (East Greenland). In
Raasch, G. O. (edit.) Geology of the Arctic 1, 197-204. Toronto U.P.

Koch, L. \& Haller, J. 1971: Geological map of East Greenland $72^{\circ}-76^{\circ}$ N. Lat. (1:250 000) Meddr Grønland 183, 26 pp.

Marcussen, C., Christiansen, F. G., Larsen, P.-H., Olsen, H., Piasecki, S., Stemmerik, L., Bojesen-Koefoed, J., Jepsen, H. F., Nøhr-Hansen, H. 1987: Studies of the onshore hydrocarbon potential in East Greenland 1986-87: fieldwork from $72^{\circ}$ to $74^{\circ}$ N. Rapp. Grønlands geol. Unders. 135, 72-81.

Marcussen, C., Larsen, P.-H., Nøhr-Hansen, H., Olsen, H., Piasecki, S. \& Stemmerik, L. 1988: Studies of the onshore hydrocarbon potential in East Greenland 1986-87: field work from $73^{\circ}$ to $76^{\circ} \mathrm{N}$. Rapp. Grønlands geol. Unders. 140, 89-95.

Säve-Söderbergh, G. 1934: Further contributions to the Devonian stratigraphy of East Greenland. II. Investigations on Gauss Peninsula. Meddr Grønland 96(2), 74 pp.

Stemmerik, L. 1988: A preliminary study of the porosity and permeability of limestones and sandstones in the Jameson Land area, central East Greenland Rapp. Gronlands geol. Unders. 140, 80-84.
P. H.-L.\&H.O., Grønlands Geologiske Undersøgelse, $\emptyset$ ster Voldgade 10, $D K-1350$ Kфbenhavn $K$, Danmark.
F. O. R.,

Danmarks Geologiske Undersøgelse, Thoravej 8 , DK-2400 København NV, Danmark.
U. G. W.

Geologisk Centralinstitut, $\emptyset$ ster Voldgade 10, $D K \cdot 1350$ Kobenhavn $K$, Danmark.

\title{
Geological investigations of Prinsesse Ingeborg Halvø, eastern North Greenland
}

\author{
Eckart Håkansson, Lena Madsen and Stig A. Schack Pedersen
}

Station Nord in Kronprins Christian Land has been the gateway to North Greenland for most geologists since the 1950s, yet little is actually known about the geology of Prinsesse Ingeborg Halvø, the low, barren stretch of land which surrounds the station. A major objective of the Ingeborg Expedition in July and August 1988 was to fill this gap by following up work initiated during the GGU expedition in 1980 (Håkansson et al., 1981).

With a central position in the on-shore part of the Wandel Hav Strike-Slip Mobile Belt (cf. Håkansson \& Pedersen, 1982), Prinsesse Ingeborg Halvø constitutes an essential element in structural correlation across eastern North Greenland. It is further located at the hinge between the North Greenland - Svalbard Rift Basin and the East Greenland - West Norway Rift Basin, which governed deposition in the early phases of the Wandel Sea Basin (cf. Håkansson \& Stemmerik, in press), thus enhancing the significance of this area for the understanding of the regional geology. Investigation of the unique, partly silicified bryozoan fauna known to abound from previous visits was an additional topic for the expedition (cf. Madsen \& Håkansson, in press).

Transport of samples and equipment within the area was by three-wheeled Honda motorcycles equipped with balloon-tires and a trailer, in much the same way as during an expedition by two of the authors to Kilen in 1985. This type of ground transport provides an adequate logistic background for smaller parties, provided the terrain is suitable and the equipment up to standard. However, the use of back-up units is advisable.

\section{Physiography}

Prinsesse Ingeborg Halvø (fig. 1) has a subdued topography with altitudes scarcely exceeding $150 \mathrm{~m}$ above sea level. The interior is made up of rolling plains draped by a veneer of soliflucted till, while the coastal 